DOI https://doi.org/10.30525/978-9934-588-37-2.2.18

\title{
ІНКЛЮЗИВНІ ТЕХНОЛОГІЇ В РОБОТІ 3 ДИТИНОЮ З ІНВАЛІДНІСТЮ
}

\author{
Чернуха Н. М., Васильсва-Халатникова М. О.
}

\section{ВСТУП}

Інклюзивна освіта - це особлива інновація, тому вимагає професійного менеджменту на всіх етапах іiі моделювання та впровадження.

Сьогоднішня ситуація в системі освіти характеризується модернізацією процесів у всіх його структурних компонентах, включаючи закон України «Про освіту», освітні стандарти, освітні програми, принципи взаємодії суб'єктів освітнього процесу, принципи організації освітнього середовища тощо. Одним 3 напрямів модернізації системи освіти є реалізація принципів інклюзивної освіти, що враховують різноманіття освітніх потреб суб'єктів освітнього процесу, їх особливостей, можливостей, інтересів. Це вимагає зміни методів, форм і технологій роботи.

Освітня технологія - це впорядкована система дій, що призводить до гарантованого досягнення соціальних і освітніх цілей. Технологія спрямована на послідовне виконання заздалегідь запланованого освітнього процесу. Незважаючи на різне розуміння терміну «освітня технологія», більшість експертів схиляються до чотирьох важливих положень:

1. Планування підготовки та освіта на основі певного бажаного результату;

2. Програмування освітнього процесу у вигляді послідовності дій суб'єктів освітнього процесу;

3. Порівняння результатів освіти з початковим призначенням, як під час освітнього процесу (моніторингу), так і під час підбиття підсумків;

4. Корегування результатів на будь-якому етапі освітнього процесу.

\section{1. Концепції «інклюзивної освіти» та «нормалізації» у роботі з дитиною з інвалідністю}

Концепція «інклюзивної освіти» (від французького “inclusif" включає в себе) є забезпечення рівного доступу до освіти для всіх, 
3 урахуванням різноманітності спеціальних освітніх потреб та індивідуальних можливостей ${ }^{1}$.

Практика включення стала можливою завдяки поширенню ідей i принципів нормалізації в суспільстві.

Концепція нормалізації була сформульована в Західній Європі в 1960-х роках ХХ століття, згідно з іï ідеями, кожна особистість є цінною, незалежно від того, яка вона і якого успіху вона може досягти; усі люди мають право на гідне повноцінне життя; суспільство має створити такі можливості для всіх ${ }^{2}$. Інклюзивна освіта - це засіб реалізації концепції нормалізації. Ідея включення полягає в необхідності зробити освіту доступною для всіх.

Інклюзивна освіта - це особлива інновація, тому вимагає професійного менеджменту на всіх етапах іiі моделювання та впровадження.

Основна ідея інклюзивної освіти - постійний моніторинг освітніх умов у всій їх повноті, щоб урахувати освітні потреби та можливості суб'єктів освітнього процесу. Коли виникають бар'єри у освітньому процесі, суб'єкти беруть участь у розробці змін, які створюють більш ефективні освітні умови. Проектування та програмування $\epsilon$ необхідними технологіями для реалізації принципів інклюзивної освіти. Таким чином, суб'єкти освітнього процесу (адміністрація закладу освіти, педагоги, фахівці, слухачі, батьки тощо) стають не тільки користувачами програм, методик, технологій, дидактичного та матеріально-технічного забезпечення, але i розробниками освітнього процесу та умов його реалізації ${ }^{3}$.

\section{2. Організаційні та освітні технології у роботі $з$ дитиною 3 інвалідністю}

Сьогоднішня ситуація в системі освіти характеризується модернізацією процесів у всіх його структурних компонентах, включаючи закон України «Про освіту», освітні стандарти, освітні програми, принципи взаємодії суб'єктів освітнього процесу, принципи

Інклюзивна освіта: теоретико-методологічні, організаційні засади впровадження : навч.-метод. посіб. / В.І. Шнайдер; Хмельниц. обл. ін-т післядиплом. пед. освіти, Каф. педагогіки і психології. Хмельницький : ОІППО, 2010. 176 с.

${ }^{2}$ Інклюзивна освіта: теорія та практика: навч.-метод. посіб. / С.П. Миронова та ін.; за заг. ред. С.П. Миронової; Кам'янець-Поділ. нац. ун-т ім. Івана Огієнка. Кам'янець-Подільський, 2012. 191 с.

${ }^{3}$ Четверікова Н. Інклюзивний клас у школі : психолого-педагогічний аспекти роботи педагогів. Київ : Шкільний світ, 2018. 136 с. 
організації освітнього середовища тощо ${ }^{4}$. Одним 3 напрямів модернізації системи освіти $є$ реалізація принципів інклюзивної освіти, що враховують різноманіття освітніх потреб суб'єктів освітнього процесу, їх особливостей, можливостей, інтересів. Це вимагає зміни методів, форм і технологій роботи.

Освітня технологія - це впорядкована система дій, що призводить до гарантованого досягнення соціальних $\mathrm{i}$ освітніх цілей ${ }^{5}$. Технологія спрямована на послідовне виконання заздалегідь запланованого освітнього процесу. Незважаючи на різне розуміння терміну «освітня технологія», більшість експертів схиляються до чотирьох важливих положень:

1. Планування підготовки та освіта на основі певного бажаного результату;

2. Програмування освітнього процесу у вигляді послідовності дій суб'єктів освітнього процесу;

3. Порівняння результатів освіти з початковим призначенням, як під час освітнього процесу (моніторингу), так і під час підбиття підсумків;

5. Корегування результатів на будь-якому етапі освітнього процесу.

Під технологіями інклюзивної освіти ми маємо на увазі ті технології, які призводять до створення умов для якісної (доступної) освіти для всіх без винятку ${ }^{6}$.

Можна виокремити дві великі групи інклюзивних технологій: організаційні та освітні технології (рис. 1).

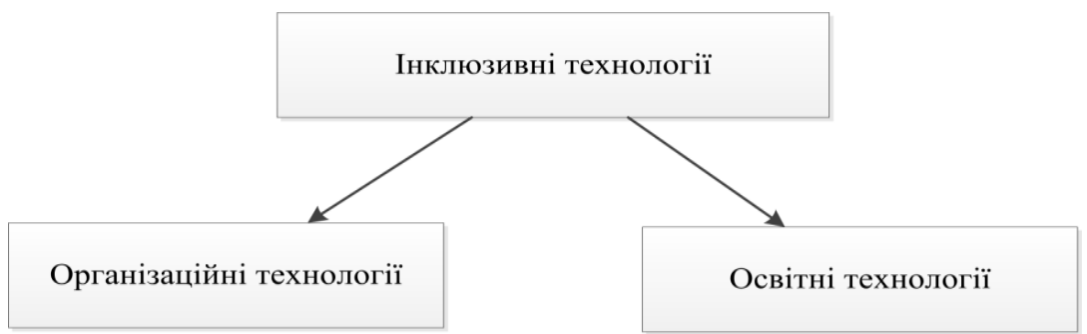

Рис. 1. Групи інклюзивних технологій у роботі з дитиною з інвалідністю

${ }^{4}$ Мальчик М.В. Компетентнісно орієнтована економічна освіта: завдання для інклюзивного навчання : навч.-метод. посіб. / Мальчик М.В., Васюк І.В., Вознюк А.Я. Дубно ; Київ : Ун-т «Україна», 2015. 320 с.

${ }^{5}$ Інклюзивна освіта: теорія та практика: навч.-метод. посіб. / С.П. Миронова та ін.; за заг. ред. С.П. Миронової; Кам'янець-Поділ. нац. ун-т ім. Івана Огієнка. Кам'янець-Подільський, 2012. 191 с.

${ }^{6}$ Інклюзивне навчання: організаційне, змістове та методичне забезпечення: навч.-метод. посіб. / Миронова С.П. та ін.; за заг. ред. Миронової С.П.; Кам'янецьПоділ. нац. ун-т ім. Івана Огієнка. Кам'янець-Подільський : К-ПНУ ім. І. Огієнка, 2015. $235 \mathrm{c}$. 
Організаційні технології пов'язані 3 етапами організації інклюзивного процесу - це технології проектування та програмування, технології командної взаємодії педагогів та фахівців, технології організації структурованого, адаптованого та доступного середовища.

Серед освітніх технологій можна виокремити ті, які можна успішно використовувати в інклюзивній практиці. Вони можуть бути класифіковані відповідно до цілей і ролі в організації спільної освіти суб'єктів з різними освітніми потребами:

1. Технології, спрямовані на засвоєння академічних компетенцій у спільній освіті суб'єктів з різними освітніми потребами: технологія диференційованого навчання, технологія індивідуалізації освітнього процесу.

2. Технологія подолання освітніх та поведінкових труднощів, які виникають у освітньому процесі.

3. Технології, спрямовані на формування соціальних компетенцій, включаючи прийняття, толерантність ${ }^{7}$.

4. Технології для оцінки досягнень в інклюзивному підході.

Розглянемо реалізацію інклюзивних технологій у роботі 3 дитиною 3 інвалідністю. Технологія індивідуалізаиї освітнього процесу. Дотримуючись загальних правил і способів організації освітньої роботи у колективі, організаторові інклюзивного освітнього середовища слід пам'ятати i врахувати тонкощі включення інклюзивного суб'єкта освітнього процесу з певними особливостями пізнавальної діяльності, поведінки, комунікації 8 . Часто він не може «наздогнати» темпи всього освітнього колективу, виконує завдання на рівні, що доступні йому. Широкі можливості індивідуалізації освіти представлені індивідуальною роботою, що відбувається в індивідуальному темпі. Індивідуалізація тут пояснюється у тому, що суб'єктам освітнього процесу не надають однакові завдання, а завдання, які враховують індивідуальні характеристики кожного.

Під час організації індивідуальної роботи в освітньому середовищі необхідно враховувати індивідуальні особливості інклюзивного суб'єкта освіти. Існує велика кількість класифікацій індивідуальних особливостей, які можуть бути використані в організації освітнього середовища. Наприклад, пропонується поширювати індивідуальні завдання на методи сприйняття інформації: для аудиалів, візуалів та кінестиків.

\footnotetext{
7 Четверікова Н. Інклюзивний клас у школі : психолого-педагогічний аспекти роботи педагогів. Київ : Шкільний світ, 2018. 136 с.

${ }^{8}$ Універсальний дизайн в освіті: посіб. для педагогів / Всеукр. фонд «Крок за кроком», Проект «Інклюз. освіта: крок за кроком»; під заг. ред., упоряд. Софій Н.З. Київ : Плеяди, 2015. 76 с.
} 
Для візуалів завдання пропонуються у вигляді листівок 3 малюнками, які повинні бути яскравими та колоритними. Для аудіалів необхідно прочитати завдання вголос. Аудіали запам'ятовують краще, коли текст повторюється неодноразово. Кінестетики отримують завдання, спрямовані на маніпулювання предметами.

Коли організатор освітнього процесу визначає рівень здібностей та знань суб'єктів освітнього процесу і, відповідно, дає їм завдання, що розподіляють їх на «сильних» та «слабких», він таким чином встановлює певний статус для суб'єкта освітнього процесу, визначає його місце в команді. Можливість змінити це місце, змінити свій статус, перейти на більш високий рівень повністю залежить від організатора освітнього процесу. Суб'єкту освітнього процесу в цьому разі виділяється пасивна роль виконавця волі організатора. Це протиріччя повинне бути розв'язане як на концептуальному, так і на технологічному рівнях. Для розв'язання цього протиріччя робиться відмінність між концепцією «індивідуального підходу», коли враховуються індивідуальні особливості суб'єкта освітнього процесу і поняття «індивідуалізація освіти» ${ }^{9}$.

Індивідуалізація освіти - це організація освітніх умов для максимальної реалізації суб'єктної позиції того, хто навчається, в освітньому процесі, тобто усвідомлення ним цілей і завдань освіти, можливість вибору освітнього матеріалу, форм і методів вирішення освітніх завдань. Таким чином, діяльність і суб'єктивність як на боці організатора, так і на боці суб'єкта освітнього процесу. Організатор створює умови для суб'єкта освітнього процесу, для того, щоб він мав можливість ставити цілі, формулювати завдання, визначати шляхи вирішення освітніх проблем, вміти оцінювати результати своїх освітніх дій. Цей процес індивідуалізації важливий як для інклюзивного суб'єкта освітнього процесу, так і для колективу. Принцип індивідуалізації створює рівні можливості для всіх, тим самим запроваджує інклюзивний підхід на практиці.

На технологічному рівні принцип індивідуалізації втілюється в різних педагогічних підходах: особистісно-орієнтована педагогіка, педагогіка підтримки, рефлексивно-діяльнісний підхід у освіті, в технологіях проектної діяльності, технологіях тьютерського супроводу ${ }^{10}$.

${ }^{9}$ Універсальний дизайн в освіті: посіб. для педагогів / Всеукр. фонд «Крок за кроком», Проект «Інклюз. освіта: крок за кроком»; під заг. ред., упоряд. Софій Н.З. Київ : Плеяди, 2015. 76 с.

${ }_{10}$ Шевців 3.М. Основи інклюзивної педагогіки: підручник. Київ : Центр учб. літ., 2016. 247 с. 
Реалізація диференційованого підходу до освітнього процесу пояснюється такими факторами: протиріччя між традиційними колективними формами освіти та індивідуальним характером засвоєння освітнього матеріалу; відмінностями у готовності до засвоєння освітнього матеріалу; різним рівнем зацікавленості суб'єктів освітнього процесу; необхідністю подолання негативного ставлення до освіти і так далі.

3.М. Шевців бачить диференційоване навчання як форму організації освітнього процесу, в якому організатор освітнього процесу працює 3 групою, створеною 3 урахуванням будь-яких спільних якостей, важливих для освітнього процесу.

Технологія рівневої диференціації освіти пов'язана 3 рівнем освоєння суб'єктом освітнього процесу програмного матеріалу. У цій технології управління пізнавальною діяльністю відбувається з метою освіти кожного суб'єкта освітнього процесу на рівні його індивідуальних можливостей і здібностей через систему малих груп. 3'являється можливість диференційовано допомагати «слабкому» суб'єкту освітнього процесу і приділяти увагу «сильнішому», більш ефективно працювати зі «слабким». У колективі виділяються три групи суб'єктів освітнього процесу залежно від можливостей засвоєння ними освітнього матеріалу (А.А. Колупаєва ${ }^{11}$, С.П. Миронова ${ }^{12}$, 3.М. Шевців ${ }^{13}$, В.І. Шнайдер ${ }^{14}$, М.С. Чайковський ${ }^{15}$ та інші). До першої групи входять суб'єкти освітнього процесу, які успішно навчаються у колективі. Вони розуміють фронтальне пояснення матеріалу, запам'ятовують матеріал, що вивчається. До другої групи належать ті суб'єкти освітнього процесу, які насилу засвоюють програмний матеріал i потребують допомоги. Вони потребують додаткового пояснення. Їх відрізняє низька самостійність. Темп засвоєння матеріалу

11 Діти з особливими освітніми потребами та організація їх навчання : наук.метод. посіб. / А.А. Колупаєва, Л.О. Савчук; Нац. акад. пед. наук, Ін-т спец. педагогіки. Вид. доповн. та переробл. Київ : Атопол, 2011. 272 с.

12 Миронова С.П. Педагогіка інклюзивної освіти: навч.-метод. посіб. / С.П. Миронова; Кам'янець-Поділ. нац. ун-т ім. Івана Огієнка. Кам'янецьПодільський : Кам'янець-Поділ. нац. ун-т ім. Івана Огієнка, 2016. 163 с.

${ }_{13}$ Шевців 3.М. Основи інклюзивної педагогіки: підручник. Київ : Центр учб. літ., 2016.247 с.

14 Інклюзивна освіта: теоретико-методологічні, організаційні засади впровадження : навч.-метод. посіб. / В.І. Шнайдер; Хмельниц. обл. ін-т післядиплом. пед. освіти, Каф. педагогіки і психології. Хмельницький : ОІППО, 2010. 176 с.

15 Чайковський М.Є. Соціально-педагогічна робота 3 молоддю 3 особливими потребами в інклюзивному освітньому просторі : монографія / Чайковський Михайло Свгенович ; Відкритий міжнар. ун-т розвитку людини «Україна», Хмельниц. ін-т соц. технологій, Луган. нац. ун-т ім. Тараса Шевченка. Київ : Ун-т «Україна», 2015. 435 с. 
у цих суб'єктів освітнього процесу значно нижчий, ніж у представників іншої групи. Значно знижена у цієї групи здатність до узагальнення. Третю групу складають суб'єкти освітнього процесу, які опановують програмний матеріал на найнижчому рівні. Знання засвоюються ними механічно, швидко забуваються. Вони можуть опанувати значно менший обсяг знань і умінь, ніж інші. Усі три групи суб'єктів освітнього процесу потребують диференційованого підходу, який передбачає різні види допомоги, різні модифікації методів та прийомів навчання.

Освіта з урахуванням індивідуальних особливостей суб'єктів освітнього процесу має місце в освітньому процесі. Наприклад, на уроці читання, закладу загальної середньої освіти, різним суб'єктам освітнього процесу пропонуються різні види переказу: хтось може переказати «близько до тексту», хтось може розповісти з опорою на картинки, але $\epsilon$ i такі, яким переказ зовсім не дається. У цьому разі організатор освітнього процесу може використовувати ілюстраціїслайди, на яких, крім картинки, $\epsilon$ текст 3 пропущеними словами. Суб'єкт освітнього процесу повинен сам згадати їх і вставити в свою розповідь. Після такої роботи багато суб'єктів освітнього процесу вже переходять до переказу з опорою на картинки, а наступна мета переказ «близько до тексту».

Технологія функціональної диференціації освіти - організація роботи в групах з розподілом функцій, тобто коли кожен суб'єкт освітнього процесу вносить свій внесок у загальний результат, виконуючи своє завдання, при цьому, інклюзивному суб'єкту освітнього процесу можна запропонувати допоміжні матеріали (наприклад, якщо потрібно скласти речення, користується заздалегідь підготовленими словами-картками, які потрібно розташувати у потрібній послідовності, під час вирішення завдання - готової коротким записом умови) ${ }^{16}$. Організація роботи в групі передбачає повну включеність суб'єкта освітнього процесу на основі розуміння його можливостей (наприклад, він може перевіряти розрахунки 3 використанням калькулятора, підбирати необхідний наочний матеріал картинки, схеми, що ілюструють зміст завдання). У такій групі хтось бере на себе функції лідера, хтось виконує певні завдання, хтось стежить за часом роботи, хтось шукає необхідну інформацію, хтось надає матеріал іншим групам. Основним критерієм ефективності

${ }^{16}$ Інклюзивне навчання: організаційне, змістове та методичне забезпечення : навч.-метод. посіб. / Миронова С.П. та ін.; за заг. ред. Миронової С.П.; Кам'янецьПоділ. нац. ун-т ім. Івана Огієнка. Кам'янець-Подільський : К-ПНУ ім. І. Огієнка, 2015. $235 \mathrm{c}$. 
групової роботи в інклюзивному освітньому середовищі стає не орієнтація на успіх - «хто більше і краще», а орієнтація на узгодженість, взаєморозуміння, підтримку, спільне прийняття рішень, вироблення компромісних рішень щодо виходу з ситуацій і так далі.

Технологія змішаної диферениіації освіти - об'єднана форма двох видів диференціації освіти - за інтересами і за рівнем розвитку ${ }^{17}$. Для вивчення навчальних дисциплін усі суб'єкти освітнього процесу групуються. Утворюються три зведені групи. Суб'єкти освітнього процесу, які цікавляться цим освітнім предметом (наприклад, географія) і мають щодо цього предмету досить високі показники, об'єднуються в одну зведену групу (тимчасовий гомогенний колектив) просунутого рівня. 3 інших суб'єктів освітнього процесу, за принципом рівневої диференціації (група базового стандарту і група посиленої соціально-педагогічної підтримки), формуються ще дві зведені групи. Розробляються три варіанти освітньої програми. Перший варіант працює в рамках групи за інтересом і має просунутий рівень; другий i третій варіанти реалізуються в тих групах, для яких цей предмет не обраний «цікавим» і головна мета яких - досягнення «обов'язкових» результатів навчання.

Технології корекиії освітніх $і$ поведінкових труднощів суб'єктів в освітньому процесі - це спеціальні логопедичні технології та технології спеціальної педагогіки, спрямовані на корекцію порушення (технології сурдопедагогіки та тифлопедагогіки), технології нейропсихологічного підходу в корекції освітніх труднощів (А.Р. Лурія, Л.С. Виготський, Дж. Хінд і так далі) ${ }^{18}$, технології психолого-педагогічної системи формування та розвитку мовного слуху і мовного спілкування у суб'єктів освітнього процесу 3 порушеннями слуху (система Е.І. Леонгард), технології прикладного аналізу поведінки АВА (Applied Behavior Analysis) та інші.

Нейропсихологічний підхід до профільних трудностей у освіті, побудований на принципах школи Л.С. Виготського, що містить загальні основи, конкретні методи та технології подолання різних видів труднощів у освіті, зумовлених недостатньою сформованістю різних психічних функцій. Нейропсихологічна корекція створена для стимуляції розвитку та формування скоординованої діяльності різних структур мозку. За допомогою розроблених рухових вправ та

17 Миронова С.П. Педагогіка інклюзивної освіти: навч.-метод. посіб.; Кам'янець-Поділ. нац. ун-т ім. Івана Огієнка. Кам'янець-Подільський : Кам'янецьПоділ. нац. ун-т ім. Івана Огієнка, 2016. 163 с.

${ }^{18}$ Інклюзивна освіта: теорія та практика: навч.-метод. посіб. / С.П. Миронова та ін. ; за заг. ред. С.П. Миронової; Кам’янець-Поділ. нац. ун-т ім. Івана Огієнка. Кам’янець-Подільський, 2012. 191 с. 
розвиваючих ігор, відбувається формування конкретних компонентів психічної діяльності: регуляція та контроль психічної діяльності, моторні навички, зорове, слухове, просторе сприйняття та багато інших.

Технології психолого-педагогічної «системи формування та розвитку мовного слуху та мовного спілкування у суб 'єктів освітнього проиесу з порушеннями слуху» (система Е.I. Леонгард). Дослідження показали, що використання цієї технології активізує мовний розвиток у суб'єктів освітнього процесу без порушень слуху. Тому рекомендації щодо формування мови та мовного слуху у суб'єктів освітнього процесу з порушеннями слуху є корисними для суб'єктів освітнього процесу без порушення слуху. Технології успішно застосовується в інклюзивній практиці ${ }^{19}$.

Серед зарубіжних технологій, спрямованих на підготовку інклюзивного суб'єкта освіти до включення в освітній процес, широко використовується така технологія, як $A B A-$ придатний аналіз або модифікаиія поведінки. Ця технологія пропонує суб'єкту освітнього процесу, адекватно визначати свої потреби, тренує навички освітньої поведінки, навички взаємодії. Під час застосування технології АВА індивідуально і в групі одне 3 основних завдань - це розвиток поведінкових та освітніх навичок, необхідних для включення інклюзивного суб'єкта освіти в освітній процес.

Технологія ТЕАССН для суб'єктів освітнього процесу 3 аутизмом передбачає як адаптацію до освітнього середовища, так і відповідні зміни у ньому, які полегшують цю адаптацію.

Технологія АAC (альтернативна аугментативна комунікація) формує у суб'єктів освітнього процесу з порушеннями мови нові навички спілкування з використанням жестів, картинок, комунікаторів $\mathrm{i}$ так далі. Ці ж навички засвоює і соціальне оточення суб'єктів освітнього процесу - педагоги, батьки, однолітки і так далі.

Технологія ерготерапї̈, створена на те, щоб навчати новим моторним навичкам, передбачає підготовку до незалежного життя та одночасно передбачає зміни у середовищі - адаптацію ігрових, побутових i освітніх матеріалів для полегшеного використання. Технологія, спрямована на розвиток соціальних компетенцій суб'єкта освітнього процесу ${ }^{20}$.

19 Миронова С.П. Педагогіка інклюзивної освіти: навч.-метод. посіб. / С.П. Миронова; Кам'янець-Поділ. нац. ун-т ім. Івана Огієнка. Кам'янецьПодільський : Кам'янець-Поділ. нац. ун-т ім. Івана Огієнка, 2016. 163 с.

${ }^{20}$ Сак Т.В. Оцінювання навчальних досягнень учнів 3 особливими освітніми потребами в інклюзивному класі: навч-метод. посіб. ; Нац. акад. пед. наук України, Ін-т спец. педагогіки. Чернівці : Букрек, 2015. 182 с. 
Одним із основних результатів інклюзивної освіти є формування життєвих навичок або соціальних компетенцій (навичок взаємодії, взаємодопомоги, продуктивної діяльності і так далі).

Можна виокремити три типи технологій, спрямованих на підвищення соиіальної компетениії: безпосереднє навчання соціальним навичкам; формування соціальних навичок через імітацію; організація групових видів активності, в тому числі ігрових ${ }^{21}$ (рис. 2).

Під час безпосереднього навчання соціальних навичок організатор освітнього процесу навчає суб'єктів освітнього процесу правильній поведінці через правила та приклади.

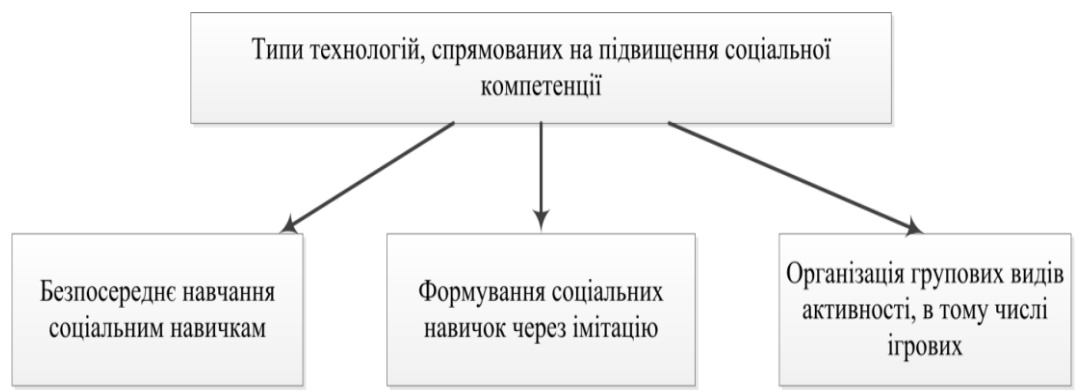

\section{Рисунок 2. Типи технологій, спрямованих на підвищення соціальної компетенції}

Прийняття правил дуже важливо для всіх суб'єктів освітнього процесу, але це має бути усвідомлено, пов'язано з власним досвідом. Перед тим, як суб'єкти освітнього процесу розпочинають роботу фронтально або у групах, організатор освітнього процесу має проаналізувати дотримання правил взаємодії суб'єктів освітнього процесу. Наприклад, «говорити за чергою», «слухати один одного», «задавати запитання, якщо щось не зрозуміло». Дуже важливо навчитись домовлятись щодо правил, якщо виникає конфліктна ситуація, як поводити собі кожному, що прийняти за основу. Організатор освітнього процесу може регулювати цей процес взаємодії. Правила мають бути простими та зрозумілими суб'єктам освітнього процесу, не суперечити один одному. Одночасно можна прийняти одне-два правила. Наступні можна вводити тільки після того, як засвоєні вже прийняті правила.

21 Мультидисціплинарний підхід як методологічна основа інклюзивного навчання: матеріали Всеукр. наук.-практ. конф., 20-21 листоп. 2012 р. м. Дніпропетровськ / Нац. акад. пед. наук України; уклад.: С. I. Васильковська, В.П. Мушинський, Н.В. Савєльєва. Дніпропетровськ. : Свідлер А.Л., 2012. 283 с. 
Суб'єкт освітнього процесу найкраще застосовує правило, коли контролює щодо його виконання іншу людину (дорослого чи дитину). Обов'язково потрібно заохочувати суб'єкта освітнього процесу за виконання правил. Суб'єкт освітнього процесу обов'язково повинен отримати позитивні підкріплення своєї діяльності.

Формування соціальних навичок через імітацію передбачає взаємонавчання суб’єктів освітнього процесу, коли більш компетентний у певній галузі стає прикладом для наслідування для інших ${ }^{22}$. Освіта через імітацію важлива для будь-якого суб'єкта освітнього процесу, але особливо воно важливо для суб'єктів освітнього процесу з затримкою психічного розвитку та розладами аутичного спектру. Тому вважається, що навчання не у однорідних, а у гетерогенних групах більш ефективне.

Під час організації групових видів активності, таких як чергування, підготовка до свята, робота у освітніх групах, допомога щодо виконання завдань, пересування в межах освітнього закладу та поза ним (наприклад, організована для суб'єктів освітнього процесу 3 проблемами зору або порушеннями опорно-рухового апарату), організатор освітнього процесу:

- планує групову активність для суб'єктів освітнього процесу, що сприяє їх ефективній соціальній взаємодії;

- обирає учасників для групи;

- вводить цю активність;

- пропонує ідеї взаємодії, коли це необхідно.

М.Є. Чайковський виокремлює взаємне (парне) навчання як одну 3 сучасних технологій інклюзивної освіти. Це ситуація, коли один суб'єкт освітнього процесу навчає іншого під наглядом організатора освітнього процесу ${ }^{23}$. Взаємне навчання продуктивно, коли $\epsilon$ необхідність розвитку навичок шляхом повторення, або на етапі закріплення сформованих навичок та умінь. Ця технологія $\epsilon$ додатковою по відношенню до інших технологій освіти. Зазвичай більш успішний суб'єкт освітнього процесу навчає менш успішного, при цьому у того, хто навчає, формується уміння самонавчання, контролю та оцінки, що своєю чергою є умовою розвитку освітньої

${ }^{22}$ Мальчик М.В. Компетентнісно орієнтована економічна освіта: завдання для інклюзивного навчання : навч.-метод. посіб. / Мальчик М.В., Васюк І.В., Вознюк А.Я. Дубно ; Київ : Ун-т «Україна», 2015. 320 с.

23 Чайковський М.Є. Соціально-педагогічна робота 3 молоддю 3 особливими потребами в інклюзивному освітньому просторі : монографія / Чайковський Михайло Євгенович ; Відкритий міжнар. ун-т розвитку людини «Україна», Хмельниц. ін-т соц. технологій, Луган. нац. ун-т ім. Тараса Шевченка. Київ : Ун-т «Україна», 2015. 435 с. 
діяльності. Водночас суб'єкт освітнього процесу, якого навчають, у процесі колективної роботи засвоює необхідний навчальний матеріал та набуває досвіду подолання труднощів. При цьому робота щодо подолання труднощів інших допомагає зрозуміти власні.

Суб'єкти освітнього процесу можуть бути як одного віку, так і різного (суб'єкт освітнього процесу більш старшого віку навчає більш молодшого віку), інший варіант - усі суб'єкти освітнього процесу розподілені на пари та виконують обов'язки тих, хто навчає, і тих, кого навчають. Інклюзивні суб'єкти освітнього процесу також можуть виступати у ролі як тих, кого навчають, так і тих, хто навчає. Це значно підвищує їх самооцінку, особливо якщо вони працюють 3 молодшими за віком суб'єктами освітнього процесу. Технологія взаємного навчання базується на припущенні, що суб'єкти освітнього процесу можуть багато чому навчитись один у одного. Включення суб'єкта освітнього процесу 3 труднощами у навчанні та поведінці у роботу в парі має відбуватись поступово. На початку з суб'єктом освітнього процесу з труднощами у навчанні мають працювати ті, хто готовий підтримати та допомогти. Це не обов'язково найкращі суб'єкти освітнього процесу, головна ознака лояльність. Однак варто пам'ятати, що потрібно бути дуже обережними під час побудови освітньої комунікації. Тому відповідно до формування у інклюзивного суб'єкта освітнього процесу умінь у галузі взаємодії, формування алгоритму діяльності під час роботи у парі, організатор освітнього процесу іiі змінює. На перших етапах він підкреслює не результат, а узгодженість, уміння співпрацювати і так далі. Можна організувати роботи у парах і за іншими принципами.

У інклюзивному освітньому процесі завдання дидактики, доступні для всіх суб'єктів освітнього процесу щодо організації спільного навчання, вирішують соиіоігрові технології (А.А. Колупаєва та інші). Їх використання дозволяє успішно включити інклюзивних суб'єктів освітнього процесу у спільне навчання, дозволяє усім суб'єктам освітнього процесу набути навички взаємодії з однолітками та створює при цьому кожному суб'єкту освітнього процесу сприятливі умови для індивідуального розвитку в своєму власному темпі.

Соціоігрові технології містять дидактичні ігри, сконструйовані на основі театральних вправ, навчальних ігор, які не тільки розвивають увагу, волю, пам'ять, мову, кмітливість, координацію рухів і так далі, але і формують навички взаємодії суб'єктів освітнього процесу між собою та організатором освітнього процесу, що $є$ важливою умовою інклюзивної освіти.

За допомогою соціоігрових технологій:

- в ігровій формі засвоюється освітня програма;

- засвоюються правила поведінки та ролі у соціальній групі (мінімоделі суспільства); 
- розглядають можливості самих груп;

- набуваються навички спільної колективної діяльності, відпрацьовуються індивідуальні характеристики суб'єктів освітнього процесу, що є необхідними для досягнення ігрових цілей;

- накопичуються культурні традиції, внесені у гру суб'єктами освітнього процесу, за допомогою додаткових засобів - наочними матеріалами, посібниками, комп'ютерними технологіями ${ }^{24}$.

У спільному освітньому середовищі здійснюється активізація та інтенсифікація освітнього процесу, ігрова діяльність використовується в таких випадках:

- як самостійні технології для опанування поняття, теми та розділу навчального предмету;

- як елемент більш загальної освітньої технології (наприклад, гра може бути використана для активізації освітньої діяльності, як мотиватор для вивчення тем);

- як освітній матеріал або його частина.

Поняття «ігрових освітніх технологій» включає в себе досить широку групу методів та прийомів організації освітніх технологій у формі різних педагогічних ігор. Педагогічна гра характеризується навчально-пізнавальною спрямованістю. Ігрова форма заняття створюється за допомогою ігрових прийомів та ситуацій, які виступають як засіб стимулювання до освітньої діяльності.

Реалізація ігрових прийомів та ситуацій відбувається відповідно до наступних напрямів:

- дидактична ціль формується перед суб'єктами освітнього процесу у формі ігрового завдання;

- освітня діяльність підпорядкована правилам гри;

- освітній матеріал використовується як їі засіб;

- у освітній діяльності впроваджується елемент змагань, який переводить дидактичне завдання в ігрове;

- успішне виконання дидактичного завдання пов'язане 3 ігровим результатом.

У об'єкт-суб'єктній взаємодії джерело знань - організатор освітнього процесу. Процес освіти може відбуватись у формі монологу (організатор освітнього процесу роз'яснює, суб'єкти освітнього процесу слухають) та у формі діалогу (чи суб'єкт освітньої діяльності задає питання організаторові освітнього процесу, чи організатор освітнього процесу проводить опитування 3 ціллю контролю). У грі немає джерела знань, усі є суб'єктами освітнього процесу. Процес

24 Діти з особливими освітніми потребами та організація їх навчання : наук.метод. посіб. / А.А. Колупаєва, Л.О. Савчук; Нац. акад. пед. наук, Ін-т спец. педагогіки. Вид. доповн. та переробл. Київ : Атопол, 2011. 272 с. 
освіти базується на діяльності, навчаються та вчать усі учасники гри у результаті активних контактів один з іншим.

Технології оцінювання досягнень в інклюзивному підході. Предметом оцінки виступають як ті освітні результати, яких досягають, так і процес їх досягнення, а також міра усвідомлення кожним суб'єктом освітнього процесу особливостей його власного процесу освіти ${ }^{25}$. При цьому поряд 3 інтегральною оцінкою (за роботу у цілому, проводить використання, наприклад, у формі портфоліо, презентацій, виставок і так далі); використовується диференційована оцінка (виділення в роботі окремих аспектів, наприклад, сформованість розрахункових умінь, виразність читання, уміння слухати, формулювати запитання і так далі), а також самооцінка та самоаналіз суб'єктів освітнього процесу.

Вибір форми поточного оцінювання визначається етапом освіти, загальними та спеціальними цілями навчання, конкретними освітніми завданнями, метою отримання інформації.

У разі освіти та оцінювання результатів діяльності суб'єкта освітньої діяльності з особливостями розвитку педагогу необхідно використовувати такі форми та прийоми, які відповідають можливостям суб'єкта освітнього процесу, є умовою збереження його фізичного та психічного здоров'я, емоційної рівноваги. Таким чином, реалізується диференційований та індивідуальний процес у освіті.

Завдання з врахуванням ступеню складності можуть розподілятись педагогом, але можливо зробити і так, щоб завдання обирали суб'єкти освітнього процесу індивідуально. У такому разі диференціація буде здійснюватись не педагогом, а суб'єктами освітнього процесу шляхом самостійного вибору завдань різного рівня складності. Таку диференціацію можна здійснити як під час опитування, так і під час засвоєння та закріплення знань.

Однією 3 технологій оцінки результатів діяльності суб'єктів освітнього процесу в інклюзії $€$ технологія самооиінювання ${ }^{26}$. Наприклад, розміщуються 2 стенди: один 3 завданнями, інший 3 відповідями. Завдання розміщуються на спеціальному стенді, розмежуються рядками, розкладаються у «кишені». Перший рядок запитань - найлегший. Другий - складніший, третій - найскладніший. Найскладніший рядок - четвертий.

У «кишені» першого рядка закладаються завдання. Зазвичай це визначення певного терміну. Необхідно цей термін визначити. Відповідь на це завдання розрахована на впізнання. Завдання другого рядка розраховані на відтворення матеріалу. Наприклад, надати визначення будь-якого поняття. У третьому рядку завдання передбачають, наприклад,

${ }^{25}$ Мудрик А.В. Социальная педагогика. Москва : 2016. 342 с.

26 Там само. 
взаємозв'язок між поняттями. Четвертий рядок представлений завданнями проблемного характеру. Завдання першого та другого рядків розраховані на роботу пам'яті, третього та четвертого - на роботу мислення.

Відповідь суб'єкта освітнього процесу оцінюється балами. Відповідь на будь-яке завдання нижнього рядка оцінюється одним балом, другого - двома, третього - трьома, четвертого - чотирма балами. Суб'єкти освітнього процесу самостійно мають право обирати завдання. Обирати завдання можна з будь-якого рядка і у будь-яких поєднаннях. Комбінацій може бути багато варіантів.

Якщо суб'єкти освітнього процесу не впорались із завданнями, то вони мають можливість змінити їх на більш легкі.

Відповідно до здійсненого аналізу було визначено наступні технології освітньої інклюзії:

1. Технології, спрямовані на засвоєння академічних компетенцій під час сумісної освіти суб'єктів освітнього процесу з різними освітніми потребами: технології диференційованого навчання, технології індивідуалізації освітнього процесу;

2. Технології корекції освітніх та поведінкових труднощів, що виникають у суб'єктів освітнього процесу в освіті;

3. Технології, спрямовані на формування соціальних компетенцій (також, прийняття, толерантність);

4. Технологія оцінювання досягнень в інклюзивному підході.

\section{ВИСНОВКИ}

Можна виокремити дві великі групи інклюзивних технологій у роботі з дитиною з інвалідністю: організаиійні та освітні технології.

Організаційні технологї пов'язані 3 етапами організації інклюзивного процесу - це технології проектування та програмування, технології командної взаємодії педагогів та фахівців, технології організації структурованого, адаптованого та доступного середовища.

На нашу думку, організаційні технології у роботі 3 дитиною 3 інвалідністю важливі у організації доступного, комфортного відповідно їх потреб освітнього середовища.

Серед освітніх технологій можна виокремити ті, які можна успішно використовувати в інклюзивної практиці. Вони можуть бути класифіковані відповідно до цілей і ролі в організації спільної освіти суб'єктів з різними освітніми потребами:

1. Технології, спрямовані на засвоєння академічних компетенцій у спільній освіті суб'єктів 3 різними освітніми потребами: технологія диференційованого навчання, технологія індивідуалізації освітнього процесу.

2. Технологія подолання освітніх та поведінкових труднощів, які виникають у освітньому процесі. 
3. Технології, спрямовані на формування соціальних компетенцій, включаючи прийняття, толерантність.

4. Технології для оцінки досягнень в інклюзивному підході.

Розкриті інклюзивні технології у роботі з дитиною з інвалідністю $є$ практико орієнтовані та потребують подальших наукових розвідок.

\section{АНОТАЦІЯ}

Інклюзивна освіта - це підхід та філософія, які припускають, що усі діти мають більше можливостей для самореалізації. Інклюзивна освіта - це підхід, за якого враховуються особливості дітей, а освітні цілі, організаційні і педагогічні умови, соціально-педагогічний супровід і діагностика, уся дидактична система враховує можливості дітей з інвалідністю та підлаштовується під їх особливості та потреби.

Можна виокремити дві великі групи інклюзивних технологій: організаційні та освітні технології. Організаційні технології пов'язані з етапами організації інклюзивного процесу - це технології проектування та програмування, технології командної взаємодії педагогів та фахівців, технології організації структурованого, адаптованого та доступного середовища.

Серед освітніх технологій можна виокремити ті, які можна успішно використовувати в інклюзивній практиці. Вони можуть бути класифіковані відповідно до цілей і ролі в організації спільної освіти суб'єктів з різними освітніми потребами: технології, спрямовані на засвоєння академічних компетенцій у спільній освіті суб'єктів з різними освітніми потребами; технологія подолання освітніх та поведінкових труднощів; технології, спрямовані на формування соціальних компетенцій; технології для оцінки досягнень в інклюзивному підході.

\section{ЛІТЕРАТУРА}

1. Байда Л.Ю. Тренінговий модуль «Міжвідомчий підхід у впровадженні інклюзивного навчання» ; Канад.-укр. проект «Інклюзивна освіта для дітей з особливими потребами в Україні». Київ, 2013. $47 \mathrm{c}$.

2. Інклюзивна освіта: теоретико-методологічні, організаційні засади впровадження : навч.-метод. посіб. / В.І. Шнайдер; Хмельниц. обл. ін-т післядиплом. пед. освіти, Каф. педагогіки і психології. Хмельницький : ОІППО, 2010. 176 с.

3. Інклюзивна освіта: теорія та практика: навч.-метод. посіб. / С.П. Миронова та ін. ; за заг. ред. С.П. Миронової ; Кам'янець-Поділ. нац. ун-т ім. Івана Огієнка. Кам'янець-Подільський, 2012. 191 с.

4. Інклюзивне навчання: організаційне, змістове та методичне забезпечення : навч.-метод. посіб. / за заг. ред. Миронової С.П. ; Кам'янець-Поділ. нац. ун-т ім. Івана Огієнка. Кам'янець-Подільський : К-ПНУ ім. І. Огієнка, 2015. 235 с. 
5. Миронова С.П. Педагогіка інклюзивної освіти: навч.-метод. посіб. / С.П. Миронова; Кам'янець-Поділ. нац. ун-т ім. Івана Огієнка. Кам'янець-Подільський : Кам'янець-Поділ. нац. ун-т ім. Івана Огієнка, 2016. 163 c.

6. Миськів Л.І. Правові проблеми інклюзивної освіти в Україні : монографія. Харків : НікаНова, 2014. 454 с.

7. Моніторинг якості освіти (інклюзивний аспект): навч. посіб. / I.О. Линьова ; Київ. ун-т ім. Бориса Грінченка, Інститут суспільства. Київ, 2012. 50 с.

8. Мудрик А.В. Социальная педагогика. Москва : 2016. 342 с.

9. Універсальний дизайн в освіті: посіб. для педагогів / Всеукр. фонд «Крок за кроком», Проект «Інклюз. освіта: крок за кроком»; під заг. ред., упоряд. Софій Н.З. Київ : Плеяди, 2015. 76 с.

10. Четверікова Н. Інклюзивний клас у школі : психологопедагогічний аспекти роботи педагогів. Київ : Шкільний світ, 2018. 136 с.

11. Чернуха Н.М., Васильєва-Халатникова М.О., Токарук Л.С. Особливості формування інклюзивного простору / Intellectual archive. Volume 7. Number 6: November/December, 2018. P. 99-108.

12. Шапаренко Г. В. Вступ до інклюзивної освіти: навч. посіб. ; Київ. ун-т ім. Бориса Грінченка, 2013. 39 с.

13. Шевців 3.М. Основи інклюзивної педагогіки: підручник. Київ : Центр учб. літ., 2016. 247 с.

14. Швед М. Основи інклюзивної освіти: підручник / М. Швед ; Укр. катол. ун-т, Гуманітар. ф-т, Каф. заг. та соц. педагогіки. Львів : Вид-во Укр. катол. ун-ту, 2015. 358 с.

15. Як зробити школу інклюзивною. Досвід проектної діяльності / Канад.-Укр. проект «Інклюзивна освіта для дітей 3 особливими потребами в Україні». Київ : Плеяди, 2012. 151 с.

\section{Information about the authors:}

Chernukha N. M.,

Doctor of Pedagogical Sciences,

Professor at the Department of Social Rehabilitation and Social Pedagogics Taras Shevchenko National University of Kyiv

2-A, Glushkova str., Kiev, Ukraine

Vasylieva-Khalatnykova M. O., Candidate of Pedagogical Sciences, Assistant Professor at the Department of Social Rehabilitation and Social Pedagogics Taras Shevchenko National University of Kyiv 2-A, Glushkova str., Kiev, Ukraine 